v. 8, n. 3

Vitória-ES, Jul. - Sep. 2011.

p. $64-82 \quad$ ISSN 1808-2386 DOI: http://dx.doi.org/10.15728/bbr.2011.8.3.4

\title{
Retail industry: seasonality in sales, and financial results
}

\author{
José Marcos Carvalho de Mesquita \\ FUMEC University \\ Henrique Cordeiro Martins ${ }^{\Omega}$ \\ FUMEC University
}

SUMMARY: This paper aims at analyzing financial performances of retail industries prone to seasonality in sales. Specifically for the Brazilian economy, three sectors had their seasonal variation pattern identified, namely: 1) hyper- and supermarkets; 2) textile, clothing, and footwear; and 3) furniture, and household appliance. Results point out a stable sales pattern in supermarket sector in comparison to the other sectors, which have peak-and-valley patterns. Subsequently, a discriminant analysis was performed to find out differences among financial indices of Brazilian companies, according to their sales patterns. According to analysis of financial ratios, companies with higher seasonal variation performed significantly better in terms of cash ratio and return on equity, whereas the other indices, debt ratio and assets turnover, account for no statistically significant differences. Building on discriminant analysis, cash ratio was found to be the most important index for discrimination.

Keywords: Seasonality in sales; retail; discriminant analysis; financial index.

Author's correspondence*:

\footnotetext{
Doctorate in Administration by the University Federal of Minas Gerais Link: FUMEC University.

Address: Rua Major Lopes, no. 738/502,

Belo Horizonte - MG - Brazil CEP 30330-050

E-mail: jmcmesquita@terra.com.br

Telephone: (31) 3342-2207
}

\footnotetext{
${ }^{\Omega}$ Doctorate in Administration by the University Federal of Minas Gerais Link: FUMEC University.

Address: Rua Professor Antônio Aleixo, no 52/201, Belo Horizonte - MG - Brazil CEP 30180-150.

E-mail: henrique.martins@fumec.br

Telephone: (31)9979-9054
}

Editor's Note: This paper was accepted by Antonio Lopo Martinez. 


\section{INTRODUCTION}

Retail industry growth is a common event in developed economies. It can be clearly identified in the Brazilian scenario by means of a simple analysis of ratios published by IBGE (Brazilian Institute for Geography and Statistics), as displayed in Table 1.

According to figure, the number of direct jobs available within retail industry increased $73.40 \%$ (from 4,843,131 in 1996 to 8,397,948 in 2007), which stands for a meaningful growth in comparison to the general Brazilian workplace, with high rates of unemployment. The number of retail stores also followed the same trend, increasing $47.52 \%$ (from 1,140,342 in 1996 to $1,682,240$ in 2007). These figures reveal that job growth was proportionally higher than the increase in the number of retail stores. Differently from the other two indices, however, real net sales had only a $52.82 \%$ increment, rising from $\mathrm{R} \$ 824,145,294$ in 1996 to $\mathrm{R} \$ 1,259,481,956$ in 2007 . In summary, this data set brings to view the actual importance of retail industry to the Brazilian economy.

Table 1 - Brazil, retail trade, selected indices, 1996-2007

\begin{tabular}{cccc}
\hline Year & Number of companies & Number of jobs & Real net sales $^{*}$ \\
\hline 1996 & $1,140,342$ & $4,843,131$ & $824,145,294$ \\
1997 & $1,088,585$ & $4,957,961$ & $852,647,254$ \\
1998 & $1,057,346$ & $4,606,316$ & $785,455,512$ \\
1999 & $1,095,534$ & $4,844,643$ & $788,556,000$ \\
2000 & $1,175,156$ & $5,366,115$ & $818,193,463$ \\
2001 & $1,340,183$ & $5,724,039$ & $849,170,439$ \\
2002 & $1,216,940$ & $5,560,581$ & $819,307,127$ \\
2003 & $1,371,116$ & $5,965,861$ & $816,690,412$ \\
2004 & $1,397,289$ & $6,360,723$ & $886,339,223$ \\
2005 & $1,444,085$ & $6,867,594$ & $1,008,068,935$ \\
2006 & $1,589,111$ & $7,557,125$ & $1,137,281,073$ \\
2007 & $1,682,240$ & $8,397,948$ & $1,259,481,956$ \\
\hline
\end{tabular}

*Deflator: General Price Index - Internal Supply (Getúlio Vargas Foundation)

Source: IBGE - Annual Trade Research

It is possible that such accelerated growth has been yielding controversial results in the industry.

On the one hand, several organizations have been performing better in terms of market share and financial results (for instance). Table 2 outlines some data that demonstrate this improvement.

The indices, except for margin on sales, are positive. Return on investment, measured as a ratio between gross profit and equity, has been relatively stable in the last years (except for 2006), as shown in values close to 7\%. A similar analysis is also found to margin on sales, which consists of dividing net profit and gross income. 
Investment over fixed assets compares the values of a given year with the immediately previous year. Values are positive in all the years within the series, which indicates ongoing growth.

The data also show negative values for sales variation (in relation to the previous year) in two periods, 2002 and 2003, years in which the Brazilian economy did not have high growth rates either.

Table 2 - Brazil, retail trade, selected indices, 2000-2007, in \%

\begin{tabular}{ccccc}
\hline Period & $\begin{array}{c}\text { Return on } \\
\text { investment }\end{array}$ & Sales growth & Margin on Sales & $\begin{array}{c}\text { Investment / } \\
\text { Fixed Assets }\end{array}$ \\
\hline 2000 & 4.9 & 6.4 & 0.6 & 21.8 \\
2001 & 6.3 & 2.4 & 0.8 & 17.2 \\
2002 & 3.3 & -1.9 & 0.5 & 24.9 \\
2003 & 7.2 & -1.5 & 1.2 & 14.7 \\
2004 & 7.3 & 11.4 & 1.4 & 25.0 \\
2005 & 8.1 & 4.8 & 1.5 & 21.8 \\
2006 & 4.7 & 4.5 & 0.7 & 29.2 \\
2007 & 7.0 & 4.7 & 1.1 & 36.3 \\
\hline
\end{tabular}

Source: Exame Magazine, Maiores e Melhores (2001-2008).

On the other hand, competition has enhanced, and every company tries to give their best in the arena of customer attraction and retention. The wide range of choices, especially because of fast development in information technology, has accounted for increasingly choosy customers likely to experience new brands and stores. In other words, companies have faced both rising difficulty to meet costumer's desired satisfaction and exponentially increasing drawbacks to build and maintain customer's loyalty.

This, however, was already posited by Vavra (1993, p. 18) when he approached market competition in mid-1993:

\begin{abstract}
Marketing professionals have most unlikely competed before as much as in the current marketplace. This is more aggressive and full of competitors, each offering relatively similar products or services. The consumers, sometimes taken as erratic, flirt with one and other brands with neither feelings of "betrayal" to a favorite brand nor fear of losing value when changing across the brands available.
\end{abstract}

Besides this hindrance, another fairly common retail industry-related factor, seasonal variation in sales, substantially widens the risk inherent to this industry. In narrow sense, seasonality, or seasonal variation, stands for a quality or a feature that is found in a given season. In wide sense, it stands for regular performance patterns determined by seasons over a given number of periods.

Sales seasonality refers to oscillations in total sales that take place throughout one year and then repeats year after year (Anderson, 1963; Brand, 1980; Reis, 1998). They do not influence the yearly sales volume, but volumes in specific periods, such as months or weeks. 
Secular variations as well as cyclical variations are also very common. In the former, variations take place on a long-term basis, whereas in the latter, variations occur on a peakand-valley basis, peaks and valleys alternating as a response to several factors, such as: climatic problems, economical crisis, political instability, etc.

Seasonality in sales strongly influences retail industry, especially because of notable dates. For instance, Christmas, followed by Mother's Day, is reported as promoting the higher sales volume, also accounting for posterior inventories for comparison reasons. Other dates are also worth notice, namely: Father's Day, Valentine's Day, Children's Day, and religious festivals (Turchi, 2009).

Such variations in sales raise concerns with stock inflows and outflows and consequent uncertainties on financial management because of high investment on working assets.

Despite its relevance, this issue has not been fairly targeted in academic discussions. Few theoretical or empirical studies have aimed at correlating marketing and financial aspects on the same perspective as this paper. This justifies any efforts to assess causes and consequences of this phenomenon.

Furthermore, this paper draws on the idiosyncratic nature of the sales seasonality phenomenon in retail sectors to scrutinize elements of this process that may contribute for better organizational performance. Because sales oscillation in retail sectors can be regarded as noises in the processes leading to the final results, it is obviously necessary to deeply understand this issue across companies. Finally, the clear-cut identification of seasonal factors related to financial indices is crucial to recognize elements that could mistakenly be attributed to seasonality, which would eventually help companies adjust their existing processes.

Thus, the general objective of this paper is to probe the impact of sales seasonality upon retail companies' financial results. More specifically, it aims to:

1. Identify seasonal pattern in sales of the sectors under scrutiny;

2. Assess whether there are differences in financial results of sectors posing (or not) major seasonality in sales.

3. Identify what set of financial indices accounts for major between-group differences. This paper is outlined in four parts, apart from this introduction including justification and objectives. Section 2 introduces topics related to seasonality in sales, risk and uncertainty, 
analysis of financial indices, and working capital management. Section 3 addresses the methodology and explanations on data, data source, and statistics measures. Section 4 reports analyses and results; and section 5 contains some final remarks, including limitations of this research.

\section{LITERATURE REVIEW}

Seasonality has been comprehensively discussed within agricultural economy, for agriculture is a prototypical season-dependent activity. According to Brandt (1980) and Reis (1998), biological features of plants account for seasonal trends in supply and thus cause price variations. More specifically, agricultural industry faces plentiful supply and low prices in harvest time, but restrict supply and high prices in the remaining period of the year, as widely known by housewives.

Other industries also face the same problem, caused, however, by increase in demand, such as: hotel industry and other services in tourist and university cities, and fashion industry (which releases two collections a year). There are also industries hindered by climatic conditions, such as heavy construction, or by reproduction cycles, such as fishery.

Seasonality in sales, however, is not widely addressed in literature. Few papers on sales management approach this issue and correlate its implications for organizations' performance. Most researches particularly concern with methods for sales predictions, including seasonal trends.

Len (1993) points out three components performing upon trade trend that must be analyzed for sales prediction: 1) secular trend, standing for increasing or decreasing movement over time; 2) seasonal trend, standing for variations over seasons; and 3) random variations, standing for unpredictable and undefined changes. The author suggests that predictions must be done by means of methods applying moving means, since they isolate effects of seasonal variations.

Similarly, Arnold (1999) states that calculating seasonal indices allows for more accurate prediction of unseasoned demand in the respective period. Seasonal index is found by dividing the demand of a specific period by the mean demand of the whole period; and then, the expected demand is divided by the monthly index found. Levy \& Weitz (2000) suggest similar procedure, by means of calculating the mean percentages that would be sold in each season, instead of seasonal indices. 
Regardless of the method, implications of seasonality can be described as follows: substantial increases in sales take place in some periods, no matter what factor causes them. They are quite predictable in terms of occurrence, but not in terms of actual magnitude. The consequent major difficult is related to the initial necessity to broaden some items in the managerial structure, such as stock, physical area, salespeople, communication media, and promotion. In other words, companies are likely to do so attempting to offset possible increase in demand. Nevertheless, the fact that increase in sales volume (just like prices) cannot be predicted accurately implies high risk. Since most products are generally specific for a given occasion, no opportunity for proper stock outflow will be found in another period. This usually causes company to develop promotional policies that may even apply reduced prices not capable to solve the whole problem.

Motta (1986) also targets seasonality-related difficulties in sales prediction. The author claims that sales prediction is one of the major issues for planning in marketing management, because several decisions depends on the accuracy of this prediction, such as: production logistics, purchase of raw material, expenses on advertisement, expenses on sales, and investment in machine and equipment.

Abernathy et al. (2000), by studying industries prone to seasonal sales correlated to retail customers' performance, say that leading retail networks have opted to reduce job order in the beginning of seasons as a means to reduce costs and minimize losses caused by lack of sales. At the same time, the authors evaluate the necessity to keep stocks because of sales variability, and they conclude that the higher the variation, the higher the necessary stock volume as a means to reduce possible losses caused by lack of merchandises.

Parente (2000) introduces cases of mistaken sales predictions, such as Brazilian customer's behavior in 1997, 1998, and 1999 Christmas. According to the author, market predicted sales reduction in relation to the same period in the former year, but there was actually growth in all these years. This may strengthen commentaries on the difficulty of making predictions with acceptable error margin. As a means to enhance prediction accuracy, the author also suggests the evaluation of macro-economical indices, such as: interest and unemployment rates; income level, and customers' expectation, including their sensitivity to price variations; price of substitute goods; product life cycle; and competition level in a given sector, that is, a retailer's marketing effort in the face of competitors' efforts.

According to Duarte Junior (2003), there are four types of risk, namely: 1) market risk: measure of uncertainty caused by market factors, such as price variations; 2) operational risk: 
measure of possible losses caused by inefficiencies in systems and internal control methods; 3) credit risk: possibility of losses because of counterparties' incapacity to pay off all liabilities; and 4) legal risk: measure of risks owing to contracts that may be not legally protected. Market risk specifically accounts for the cases approached in this paper, that is, actual sales cannot offset sales predictions because some unique conditions related to market performance may not come true.

Fusco (1996) explains that increase in sales builds similar needs in inventories, accounts receivable, and cash balance sheet, all of them demanding some funding. Increase in sales implies business-related uncertainty because of four major factors, namely: 1) sales uncertainty, related to new customer's behavior; 2) uncertainty on receipt rate because of increase in number of new customers having different payment patterns; 3) uncertainty on production cost owing to higher operational leverage and insecurity regarding input availability; and 4) uncertainty related to cash outflow owing to new liabilities and possibility of imbalance with respective cash inflow. The author also states that growth in cost curve may overcome growth in income curve in some domain in such a way that sales growth may become inefficient for an organization.

In a different way, financial management has faced seasonal variations more accurately. According to several authors, such as Brealey \& Myers (1992), Gitman (1997), Ross et al. (2002), and Weston \& Brigham (2002), regardless of some possible terminology differences, an organization's operating cycle can be defined as the average time between purchasing inventory and receiving cash proceeds from its sale. Similarly, cash cycle stands for the period raging from effective payment for raw material acquisition and collection for finished sales. The respective mathematical function defined by financial indices would be:

$$
\begin{aligned}
& O C=D I+A C P \\
& C C=D I+A C P-A P P
\end{aligned}
$$

In which:

OC stands for operating cycle;

$\mathrm{CC}$ stands for cash cycle;

DI stands for days inventory;

ACP stands for average collection period;

APP stands for average payment period; 
As expressed in their very names, these ratios stand for average periods. Days inventory is the time it takes for a company to receive raw material, stock it, manufacture it, stock finished merchandises, and sale them (remembering that manufacturing is not a part of the process in a commercial company). Average collection period is the time it takes for a company to collect bills receivable, that is, the time a certain company finances their customers. Average payment period stands for the time it takes for a company to pay its debts, that is, the time a company is financed by its suppliers.

In thesis, seasonality per se should not account for variations in cash and operational cycles. Nevertheless, as described by Motta (1986), Fuscuo (1996) Albernathy et al. (2000), the prediction of sales growth in specific dates is assumed to make retail organizations purchase in advance, which in turn may enlarge their stock period.

Moreover, because giving credit to costumers has become a common practice in retail industry, acquisition has become easier and more attractive for a great number of purchasers who would not do so if they did not have the possibility to pay in installments - this, in turn, also implies a larger period for collection (Parente, 2000, p. 277; Sheth et al, 2001, p. 81). According to Lima et al. (2009), there was a significant, ongoing growth in credit lending after the implementation of the new Brazilian currency (Real, in 1994), which reflected the process of income distribution.

In case of no change in payment periods established by suppliers, only these two effects perform upon cash and operational cycle. However, consequences in terms of need of working capital may be quite significant. In other words, purchasing in advance and giving credit may cause companies to increase their need for working capital and, consequently, to increase their financial costs.

Although it is not a certainty that a company will need some loan because of changes in cash and operating cycles, prediction in sales increment will surely yield increase in investment in working assets (Fusco, 1996). Obviously, larger sales demand larger stocks, which accounts for larger sales volume and necessity to increase working capital, unless a company manages to operate in negative cash cycle (i.e., payments carried out after collections).

This creates what the authors like Brealey \& Myers (1992), Gitman (1997), Ross et al. (2002) and Weston \& Brigham (2002) have termed fixed working assets and seasonal working assets. Although the ways to manage great need of working capital is believed to 
vary from company to company, ranging from aggressive to conservative strategies, depending on financing origins, the thing is that the phenomenon is common to all the organization facing seasonal variations in their sales.

The authors point out that several companies prefer investing in marketable securities in surplus periods to selling them in deficit periods. Such a policy may minimize risk of default that is typical in sales variations, yet it may also reduce profitability, as working assets are less profitable than long-term assets and fixed assets. Thus, accurate management of sales variation is crucial to prediction and fine administration of financing needs.

Besides impacts on working capital, other possible effects might affect indices related to profitability, debt, and activity. Several authors, such as Brealy \& Myers (1992), Gitmam (1997), Ross et al. (2002), and Weston \& Brigham (2000), address this issue. First, according to them, profitability ratio measures a company's efficiency in generating returns. Return on equity, more specifically, reveals how much profit an organization has generated per each monetary unit of its own capital. Although keeping high working capital may undermine profitability, several other factors usually cause meaningful impacts, especially those related to long-term strategies, such as investment in fixed assets and policies on larger market share, and also macro-economical conditions, in terms of population's average income, interest rates, price levels, and customers' loyalty. Second, debt indices stand for financial leverage used by an organization and reflect both the possibility of profit (on the one hand) and involved risk (on the other hand). Debt ratio involves total liabilities in relation to total assets. In general terms, the greater the income stability, the higher the possibility of debt, supposing higher security regarding payments accomplished. Finally, activity indices show a company's capacity to transform bills into cash. The ratio assets turnover shows a company's capacity to sale in relation to total amount invested, that is, the efficiency in management of investments in assets. In general terms, this index is strictly related to activity type, and is generally low in those activities that need large amount of fixed assets, especially manufacturing companies. It all means that there are no striking variations caused by seasonality in sales.

\section{METHODOLOGY}

According to Hair et al. (2005b), Malhotra (2001) and Mattar (2005), the nature of relationship between variables under scrutiny and depth level of the conclusions achieved determines the kind of research. This study aims at assessing the relationship between seasonality in sales and financial performance. More specifically, it aims at checking whether 
there are differences between financial indices found for companies that have some or no seasonality in sales. This paper, thus, poses a descriptive nature, in the authors' terms.

The sectors chosen for this study are: hyper- and supermarket; textile, clothing, and footwear; and 3) furniture, and household appliance. This is a choice due to the fact that such sectors, at least in thesis, involve different seasonal patterns, besides being relevant to the Brazilian economy in terms of total sales, job supply and payment of taxes, according to data from $\mathrm{IBGE}^{\mathrm{i}}$.

This research addresses the following sectors: hyper- and supermarkets; textile, clothing, and footwear; and furniture, and household appliance. These sectors were chose because of their probably different patterns of seasonality in sales and also because of their importance in the Brazilian economy, in terms of revenue, employment generation, and tax collection.

This section particularly introduces analysis techniques designed for each specific objective. The first one is to identify the sales seasonal pattern of the sectors under scrutiny, by calculating the sales seasonal indices consistent with the technique of geometric moving average as proposed by Hoffmann (1991). Data related to monthly revenue were found in IBGE and stand for nominal sales indices, 2003 equals to 100. The historical series range from January 2000 through December 2006 and sum up 84 observations.

After finding seasonal indices, sectors having or not high variations were identified drawing on indices range, as proposed in Hoffmann (1991), coefficient of variation and homoscedasticity, based on the Box M test. As a result, companies must fall into one of two different groups, namely: group I, for companies with little seasonality in sales; and group II, for companies with high season variation.

The second objective aims at assess the existence of differences in financial performance of companies with different sales seasonality patterns, that is, if there are differences in financial results between those companies that had high sales season variation and those having regular sales patterns over the year. Four financial indices from several retailers were applied to meet this objective, namely: cash ratio; debt ration; assets turnover; and return on equity. A discriminating analysis, as proposed in Hair et al. (2005a) and Sharma (1997), estimated a function that would select companies according to their origin classification - group I (low seasonality), or group II (high seasonality) - in order to enhance differences between financial indices found for each group. 
Specific tests performed assumptions' diagnostics, namely: Shapiro-Wilks' and Kolmogorov-Smirnov' tests assessed univariate normality, and Levene's and Box's M tests assessed homoscedasticity. Results were selected building on criteria involving discriminating power measured in terms of accurate classifications, explanation power found by means of canonical correlation, and statistical significance of the estimated function.

The sample is composed of 18 retail trade-oriented companies (Appendix I) that fall into one of the sectors under scrutiny in this paper. Data found in Brazilian economy- and management-oriented magazines - Exame (2000-2007) and Conjuntura Econômica (20002007) comprise the following indices:

- Cash ratio (in index): sum of working assets plus non-current assets, divided by total liabilities, except for discounted notes;

- Return on equity (in percentage): division of net profit by equity;

- Debt ratio (in percentage): sum of current liability and long-term liability, divided by total assets;

- Assets turnover (in index): gross sales revenue divided by total assets.

After discriminating analysis, a review for the third specific objective was carried out to assess what groups of financial indices would be decisive for differences among sectors, especially among companies having differentiated sales seasonal patterns.

This sampling comprises big, medium and small publicly held companies and closed corporations. Data under scrutiny stands for 2000-2007 financial statements related to 19992006 fiscal periods. The number of observations is 107, since not all companies had their financial statements listed every year. It is also worth notice that categorization of companies in three groups according to branch of performance built exclusively on the main business of each organization, despite the fact that some companies, especially hypermarkets, trade other products. It is likely that such possible duplicity has not blurred the results outlined in this paper.

\section{RESULTS AND DISCUSSION}

The first results are related to seasonality in sales. As shown in Table 3 and Graph 1, textile, clothing and footwear sector, as well as household appliance sector, labeled group II, are more prone to seasonal variation than hyper- and supermarket sector, group I. Building on 
such a categorization, the number of observations falling into each group is 42 in group I and 65 into group II.

The initial analysis of seasonal indices displays monthly sales patterns in relation to performance in the historical series under scrutiny. Indices in each month stand for a sector's sales value within average sales equal to 100 (for instance, hyper- and supermarket would sell $96.1 \%$ of average value in January).

Table 3 - Brazil, sales seasonality indices: Selected indices, 2000-2006

\begin{tabular}{cccc}
\hline Months & $\begin{array}{c}\text { Hypermarkets and } \\
\text { supermarket }\end{array}$ & $\begin{array}{c}\text { Textiles, clothing, and } \\
\text { footwear }\end{array}$ & $\begin{array}{c}\text { Furniture and household } \\
\text { appliance }\end{array}$ \\
\hline January & 96.1 & 77.6 & 93.7 \\
February & 91.6 & 74.0 & 81.9 \\
March & 100.8 & 83.0 & 93.7 \\
April & 99.2 & 86.5 & 90.2 \\
May & 97.6 & 108.4 & 105.2 \\
June & 94.8 & 98.9 & 91.7 \\
July & 98.7 & 98.4 & 96.4 \\
August & 98.8 & 95.7 & 97.5 \\
September & 96.3 & 85.6 & 90.9 \\
October & 100.7 & 94.4 & 99.7 \\
November & 98.3 & 102.7 & 101.2 \\
December & 127.3 & 194.8 & 157.9 \\
\hline
\end{tabular}

Source: IBGE (www.ibge.gov.br)

Table and graph based analyses indicate that textile, clothing and footwear sector as well as furniture and household appliance sector display seasonal variation quite superior to those found in hyper and supermarket sector.

Such assertive is confirmed by a Box's M test resulting in 14.654 and transformed into an F statistics of 7.078 at a significance level of 0.00 . Therefore, the variations in the indexes are said to be statistically relevant.

On the one hand, the two former sectors have increasing variations in May and December, whereas the latter has increasing variations only in December and at relatively lower ratios. On the other hand, substantial downfall over the other periods of the year is not found for hyper and supermarket sector, but it is for the other two sectors. For all of them, however, lower sales volume take place in February, which can be explained by the number of days in this month. In other words, outstanding seasonal variations are found for group 2 (with higher sales volumes in May and December, owing respectively to Mother's Day and Christmas, both deemed as the most important notable dates of the year). 


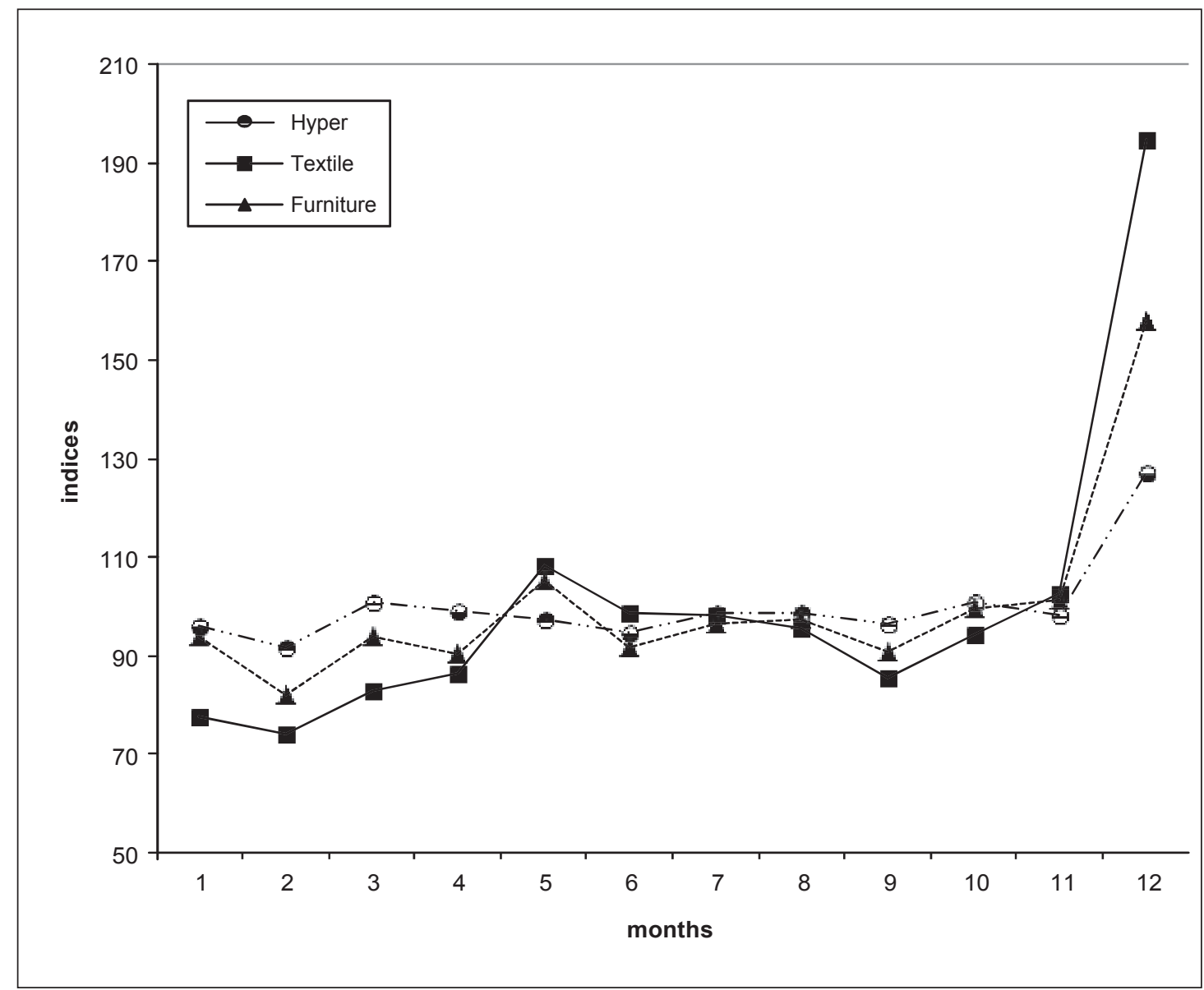

Graph 1 - Brazil - Sales seasonality indices: selected indices, 2000-2006

Source: Research data.

Table 4 presents descriptive statistics from data related to companies' financial performance under discriminating analysis. The sample contains 107 observations, from 18 companies, 9 for each group. Annual data are this way: 8 observations in group I and 9 in group II in 2000; respectively 5 and 8, in 2001, 5 and 9, in 2002; 7 and 6, in 2003; 5 and 9, in 2004; 5 and 8, in 2005; 4 and 8, in 2006 and; 3 and 8, in 2007.

Table 4 - Indices of selected companies' financial performance, 2000-2007

\begin{tabular}{lcccc}
\hline \multirow{2}{*}{ Index } & \multicolumn{2}{c}{ Group I (9 companies) } & \multicolumn{2}{c}{ Group II (9 companies) } \\
& Mean & Standard deviation & Mean & Standard deviation \\
\hline Cash ratio & 0.84 & 0.33 & 1.46 & 0.88 \\
Debt ratio & 58.31 & 12.15 & 61.62 & 20.01 \\
Return on equity & -2.26 & 20.64 & 6.08 & 12.95 \\
Assets turnover & 1.76 & 0.89 & 1.53 & 0.49 \\
\hline Source: Exame (2000, 2007) and Conjuntura Econômica $(2000,2007)$ Magazines.
\end{tabular}

Some of the financial indices analyzed have shown between-group differences. In group I, profitability measured in return on equity was negative in the period, whereas Group II had a positive average index and lower standard deviation. In both groups, standard deviation is superior to the mean. Regarding debt ratio and total assets turnover indices, no statistically significant differences were found. Although hyper- and supermarkets had lower 
debt and superior assets turnover in average values, between-group percentage differences are very small. Concerning cash ratio, group II had statistically significant, superior values (difference reaches $73.8 \%$ in average values).

Consistent with discriminating analysis designed in Hair et al. (2005), the number of observations is adequate and even outnumbers the suggested value of 20 observations for each independent variable. Shapiro-Wilks and Kolmogorov-Smirnov tests for assumption diagnostics indicated that data were far from normal distribution. Owing to this result, a transformation by means of natural logarithm was performed, and generated satisfactory results for cash ratio, debt ratio, and assets turnover (i.e., for such variables, the transformed data were normally distributed). Specifically for return on equity, the inverse was calculated and did not result in data normality. Furthermore, Box's M test indicated unequal covariance matrices at a significance level of 0.00 ; yet Levene's univariate test showed statistically significant difference only for variable debt index. Despite these results, sample size, technique strength regarding violations, and only one variable violating each assumption ensure analysis validity.

Another important assessment refers to correlation level between independent variables. Pearson's correlation coefficient indicates significant co-linearity for both cash ratio and debt ratio at $1 \%$ level and for both debt index and assets turnover at 5\% level. However, such a violation was disregarded because of the nature of both variables and analysis.

Results in Table 5 show that both cash ratio and return on equity means are different for both groups at 0.00 and 0.03 significance level, respectively. The hypothesis of equality between means for the other two indices can not be declined, as already predicted with a simple analysis of descriptive statistics. In other words, both financial ratios are very similar for both groups, despite meaningful differences in their sales seasonal patterns. This suggests that there is no influence of trade variations upon financial performance regarding assets turnover and debt ratios.

Table 5 - Test of equality of group means

\begin{tabular}{lccc}
\hline \multicolumn{1}{c}{ Variable } & Wilks' lambda & F-test & Significance \\
\hline Ln cash ratio & 0.742 & 36.603 & 0.000 \\
Ln debt ratio & 1.000 & 0.024 & 0.877 \\
Ln total assets turnover & 0.988 & 1.283 & 0.260 \\
1/return on equity & 0.956 & 4.842 & 0.030 \\
\hline Source: Research data. & & &
\end{tabular}

Despite variables equality, discriminating analysis included all the variables. Results are shown in Tables $6,7,8$ and 9. 
Table 6 - Canonical discriminating functions

\begin{tabular}{ccccc}
\hline Function & Eigenvalue & Variance $\%$ & Cumulative \% & Canonical correlation \\
1 & 2.011 & 100.0 & 100.0 & 0.817 \\
After function & Wilks' lambda & Chi-square & $\mathrm{Gl}$ & Significance \\
1 & 0.332 & 113.540 & 4 & 0.000 \\
\hline
\end{tabular}

Source: Research data.

The estimated function has high efficiency for group differentiation, since a 0.000 relevance level is very high. The 0.817 canonical correlation indicates that $66.7 \%$ of betweengroup variation are explained by discriminating function. In other words, independent variables included in the model (cash ratio, debt ratio, assets turnover, and return on equity) are capable to explain most sales seasonality-related differences between companies' performance.

Table 7 - Summary of interpretative measure of the canonical discriminating function

\begin{tabular}{lccc}
\hline \multicolumn{1}{c}{ Independent variable } & Standardized Coefficients & $\begin{array}{c}\text { Non-standardized } \\
\text { coefficients }\end{array}$ & Discriminating Loadings \\
\hline Ln cash ratio & 2.190 & 5.212 & 0.416 \\
Ln debt ratio & 2.037 & 6.099 & 0.011 \\
Ln assets turnover & -0.587 & -1.598 & -0.078 \\
1/return on equity & -0.135 & -0.124 & -0.151 \\
Constant & & -24.345 & \\
\hline
\end{tabular}

Source: Research data

On the one hand, non-standardized coefficients are applied to calculate z-score for each observation. Z-score must later be compared to cut-off score (equal to -0.6187) calculated in function of different group sizes. It means a company may fall either into group I if its $\mathrm{z}$-score is less than -0.6187 or into group II if its $\mathrm{z}$-score is higher than -0.6187 . On the other hand, standardized coefficients show that variables are significant in the estimate function (in decreasing order) for cash ratio, debt ratio, total assets turnover, and return on equity.

Nevertheless, categorical analysis related to the importance of each variable must draw on discriminating loadings, which indicate the variance shared by the independent variables with the discriminating function. In this perspective, cash ratio is the only variable responsible for discrimination, since the other three variables do not reach the minimum value $(=0.3)$. This analysis, thus, confirms results from univariate analysis and indicates cash ratio as the major between-group difference.

Table 8 - Group centroids

\begin{tabular}{lc}
\hline & Troup centroids: function 1 \\
\hline Group I & -1.748 \\
Group II & 1.129 \\
\hline Source: Research data. &
\end{tabular}


Group centroids allow for general assessment of discriminating function and enhance the highly significant discrimination level reached in the analysis.

Table 9 - Classification matrix ${ }^{*}$

\begin{tabular}{lccc}
\hline & & \multicolumn{2}{c}{ Predicted membership } \\
Type & Number of cases & Group I & Group II \\
\hline Group I & 42 & 38 & 4 \\
Group II & 65 & 0 & 65 \\
& Percentage & Group I & Group II \\
Group I & 100 & 90.5 & 9.5 \\
Group II & 100 & 0.0 & 100.0 \\
\hline
\end{tabular}

*96.3\% of the accurately classified cases.

Source: Research data

The classification matrix is an ancillary result of discriminating function. For this sample, $96.3 \%$ of the observations were correctly classified, $90.5 \%$ for group I, and $100 \%$ for group 22. This is a very high index that enhances the discriminating power of the estimated function.

\section{FINAL REMARKS}

The results outlined in section 4 figures the major differences between the two groups of companies under scrutiny in this paper. Hyper- and supermarket sector, group I, is less prone to sales seasonal variations than group II, which includes textile, clothing and footwear sector as well as furniture and household appliance sector.

The estimated discriminating function had high significance and high discriminating power. It means that all indices in the analysis play a role in enhancing between-group differences, regardless of univariate differences observed in only two financial indices when they were analyzed as a whole.

In short, companies in group I (having less sales seasonal variation) and companies in group II (having large variations) performed similarly in terms of total assets turnover and debt ratio. However, group II had quite superior profitability; companies in this group had higher investment in working assets, which is necessary $\mathrm{n}$ the face of sales-related uncertainty.

Although some authors, such as Brealy \& Myers (1992), Gitman (1997), Ross et al. (2002), and Weston \& Brigham (2000), suggest that more stability in sales, in thesis, accounts for more debt ratio, such a fact was not found in the analysis. The authors also say that assets turnover is more related to branch of performance and does not vary in function of seasonality in sales, as effectively verified in the sample. 
However, companies in group II endeavored to invest more in working assets, probably as a means to prevent themselves from sales variation. This, according to Duarte Junior (2003) and Fusco (1996), is a cautious and apparently successful strategy. However, the initial expectation would be contrary to the result, since higher investments in working assets are likely to yield lower profitability rates. At any rate, profitability depends on high sector-related margin magnitude and macro-economical variables, and both these features go beyond the purpose and scope of this paper.

In general, this paper is expected to contribute with two major propositions for the studies on the issue under scrutiny. First, retail industries involving sectors like textile, clothing and footwear as well as furniture and household appliance have had a greater seasonality pattern than the sector of hyper- and supermarkets. This seasonality, in turn, highlights the differences between the financial indices of both groups. Second, despite seasonality differences, indices like assets turnover and debt ratio do not show high oscillation both in companies with higher or lower seasonality. However, companies with the highest seasonality indices for profitability such indices proved to be superior to those found in organizations with lower seasonality. Therefore, we can hypothesize that companies with higher seasonality are likely to manage their working assets more effectively by means of prudent strategies to cope with high oscillations in such phenomena.

Finally, this paper involves some limitations that can be offset in further and future researches. Because it involves an unusual approach and no cause-effect analysis was carried out, this paper does not provide the causal relation between profitability and sales seasonal variation. In other words, it does not identify whether sales variations are likely to influence profitability; it only observes that companies with stronger seasonal pattern have more profitability. Therefore, researches approaching this effect by means of analysis of trade margins and influences of macro-economical indices (e.g., interest rates, income, price index) would be very relevant both for academic and managerial communities.

Besides, data used in this research involve companies all over Brazil, and do not account for possible regional differences related to seasonality in sales. Such an analysis would be very insightful for it can provide different outputs against Brazilian multi-diverse cultural background. In this sense, regional-scope researches would overcome this shortcoming.

Another limitation concerns the use of secondary (but hardly comprehensive) data found in specialized magazine to meet the purpose of researching both publicly held 
companies and closed corporations to widen research universe. Future researches aiming at collecting and analyzing data from managerial reports (in case of no publication of mandatory financial statements) would address a higher number and diversity of indices. They would also analyze data related to shorter financial periods (e.g., quarters, or semesters), which would point out more accurate seasonal effects.

Finally, the results generalization isn't possible due to the small data sample, although many attempts to enlarge it were done.

\section{REFERENCES}

ALBERNATHY, F. H.; DUNLOP, J. T.; HAMMOND, J. H.; WEIL, D. Control your Inventory: in a world of lean retailing. Harvard Business Review, Boston, Nov. / Dec. 2000.

ARNOLD, J. R. T. Administração de materiais: uma introdução. São Paulo: Atlas, 1999.

BRANDT, S. A. Comercialização agrícola. Piracicaba: Livroceres, 1980.

BREALEY, R. A.; MYERS, S. C. Princípios de finanças empresariais. 3 ed. Portugal: McGraw-Hill, 1992.

CONJUNTURA ECONÔMICA. 500 maiores. Rio de Janeiro: Fundação Getúlio Vargas, 2000-2007.

DUARTE JUNIOR, A. M. A Importância do gerenciamento de riscos corporativos em bancos. In: DUARTE JUNIOR, A. M.; VARGA, G. Gestão de riscos no Brasil. Rio de Janeiro: Financial Consultoria, 2003.

EXAME, Maiores e melhores. São Paulo: Editora Abril, 2000-2008.

FUSCO, J. P. A. Necessidade de capital de giro e nível de vendas. Revista de Administração de Empresas, São Paulo, v. 36, n. 2, Apr. / June 1996.

GITMAN, L. J. Princípios de administração financeira. São Paulo: Harbra, 1997.

HAIR JUNIOR, J. F.; ANDERSON, R. E.; TATHAM, R. L; BLACK, W. C. Análise multivariada de dados. Porto Alegre: Bookman, 2005a.

HAIR JUNIOR, J. F.; BABIN, B.; MONEY, A. H.; SAMOUEL, P. Fundamentos de métodos de pesquisa em administração. Porto Alegre: Bookman, $2005 \mathrm{~b}$.

HOFFMANN, R. Estatística para Economistas. 2 ed. São Paulo: Livraria Pioneira Editora, 1991.

INSTITUTO BRASILEIRO DE GEOGRAFIA E ESTATÍSTICA - IBGE. Available at: $<$ www.ibge.gov.br>. Accessed on: Dec. 15, 2007.

INSTITUTO DE PESQUISA ECONÔMICA APLICADA - IPEA. Available at: $<$ www.ipeadata.gov.br>. Acessed on: Dec. 15, 2007.

LEN, R. Administração de vendas e marketing. São Paulo: Makron Books, 1993.

LEVY, M.; WEITZ, B. A. Administração de varejo. São Paulo: Atlas, 2000.

MALHOTRA, N. K. Pesquisa de marketing: uma orientação aplicada. Porto Alegre:

Bookman, 2001.

MATTAR, F. N. Pesquisa de marketing. São Paulo: Atlas, 2005. 
MOTTA, J. Como Reduzir a incerteza em previsão de vendas. Rio de Janeiro: Revista de Administração de Empresas, v. 26, n. 1, Jan. / Mar. 1986.

PARENTE, J. Varejo no Brasil: gestão e estratégia. São Paulo: Atlas, 2000.

REIS, A. J. Comercialização agrícola no contexto agroindustrial. Lavras: FAEPE, 1998.

ROSS, S. A., WESTERFIELD, R. W.; JAFFE, J. F. Administração financeira. São Paulo: Atlas, 2002.

SHARMA, S. Applied multivariate techniques. USA: John Wiley \& Sons, 1996. vou conferir

TURCHI, S. A sazonalidade do consumo. Disponível em <www.mundodomarketing.com.br $>$ Acesso em 22/09/2009

VAVRA, T. G. Marketing de Relacionamento: aftermarketing. São Paulo: Atlas, 1993. 323 p.

WESTON, J. F. e BRIGHAM, E. F. Fundamentos da administração financeira. São Paulo: Pearson Education, 2000.

\section{APPENDIX}

List of companies under scrutiny

\begin{tabular}{cc}
\hline Group I & Group II \\
\hline Pão de Açúcar & Ponto Frio \\
Sendas & Lojas Americanas \\
Sonae & Pernambucanas \\
Bom Preço & Lojas Colombo \\
Bom Preço Bahia & Riachuelo \\
Zaffari & Magazine Luiza \\
Eldorado & Lojas Cem \\
Abc Supermercados & Lojas Renner \\
Zona Sul & Lojas Yamada \\
\hline
\end{tabular}

Notes:

${ }^{\mathrm{i}}$ Available at: www.ibge.gov.br. 